Studia z Filologii Polskiej

i Słowiańskiej, 46

SOW, Warszawa 2011

Maciej Czerwiński

\title{
Sens dziejów narodowych a struktura tekstu historycznego. O niektórych mechanizmach tekstotwórczych na przykładzie historii Polski
}

W artykule niniejszym spróbuję rozważyć kilka istotnych zjawisk tekstotwórczych, pełniących również funkcje sensotwórcze, charakterystycznych dla syntezy dziejów narodu, przede wszystkim zaś strategiczną rolę finatu i związaną z nim strukturę narracji odpowiadającą za ustanawianie porządku w dyskursie traktującym o historycznym świecie pozajęzykowym.

\section{Wprowadzenie}

Tekst traktujący o przeszłości stał się w ostatnim czasie - za sprawą wielu czynników pozanaukowych i najbardziej pospolitych mód - przedmiotem dogłębnych refleksji i badań w obrębie wielu dyscyplin humanistycznychํㅡ. Co więcej, nowe zainteresowanie przeszłością szybko przeniknęło do środków

${ }^{1}$ Zajmują się nim - w tym narracją jako formą podawczą - teoretycy historii i historycy (np. Hayden White, Jerzy Topolski), filozofowie (np. Frank Ankers mit, Katarzyna Rosner), lingwiści i literaturoznawcy (np. Teun van Dijk, Michał Głowiński, Bożena Wit os z, Aleksander Wilkoń, Stefania Skwarczyńska, Teresa Skubalanka). 
masowego przekazu, w rezultacie czego termin narracja, mający w lingwistyce i naukach pokrewnych znaczenie wąsko specjalistyczne (choć niejednoznaczne i ciągle podlegające dyskusji), uległ daleko idącemu upotocznieniu. Jak zwykle łapczywe media, w poszukiwaniu efektownej formy dla swoich najczęściej miernej jakości treści, wykradły go z gmachu nauki i zaanektowały na własne potrzeby (warto przy tym odnotować rzecz znamienną: otóż pod naporem nowej mody wyparty został inny dotąd popularny terminologizm - dyskurs). Dziś już każdy szanujący się publicysta używa terminu narracja, ale najczęściej nie rozumie jego specjalistycznej treści. W efekcie leksem ów można znaleźć w niespotykanych dotąd kontekstach, których analiza byłaby zapewne wdzięcznym przedmiotem badań. Rozpaczanie nad takim stanem rzeczy nie ma sensu, wszakże mamy tu do czynienia ze zwyczajnym zjawiskiem determinologizacji (można się co najwyżej zachwycać potęgą języka lub doprawdy godnym podziwu tupetem dysponentów języka mediów).

Dla badacza zajmującego się tekstem historycznym problem narracji i innych związanych $\mathrm{z}$ nią mechanizmów jest jednak zupełnie innego rodzaju. Może go między innymi interesować sposób, w jaki owa narracja (a więc znakowa reprezentacja historyczna) powstaje oraz zjawiska sensotwórcze i kulturotwórcze z tym powstawaniem skorelowane. Nie ma bowiem wątpliwości, że tekst historyczny ma inny status aniżeli jakikolwiek inny tekst, co wynika chociażby $\mathrm{z}$ tego, że odnosi się do świata, który już jakiś dłuższy czas $\mathrm{n}$ ie i s t n i e j e. Język - rozumiany jako kompleksowy system semiotyczny - użyty $\mathrm{w}$ tekście historycznym u ob e $\mathrm{n}$ i a więc (zgodnie $\mathrm{z}$ doktryną semiotyczną: reprezentuje czy zastępuje) stany rzeczy, które już nie istnieją, więc trudno go zweryfikować empirycznie. Co więcej, historycy w swojej pracy naukowej najczęściej posługują się dokumentami, czyli tekstami - a zatem konkretnymi parole wcześniej istniejących langue. Upośrednienie reprezentacji historycznej jest więc znacznie bardziej złożone aniżeli tekstów odnoszących się albo do teraźniejszości, albo do bliskiej przeszłości.

Podobnie rzecz jasna jest $\mathrm{z}$ tekstami historycznymi, których prototypowym odbiorcą nie jest wykwalifikowany historyk, lecz przeciętny obywatel danego kraju, na przykład Polak poszukujący podstawowych informacji na temat historii własnego kraju (należy jednakowoż odnotować, że takie popularnonaukowe gatunki są jeszcze bardziej narażone na wtórność, gdyż autorzy opierają się niemal wyłącznie na gotowych interpretacjach i obiegowych tezach, nie zaś na nowych badaniach archiwalnych ${ }^{2}$ ). To dla takiego właśnie

${ }^{2}$ Nie oznacza to oczywiście, że tego rodzaju książki nic do nauki nie wnoszą, przeciwnie - mogą jakiś problem ująć w zupełnie nowy sposób. 
odbiorcy przeznaczone są syntezy dziejów narodu. Mają one osobliwą budowę stylistyczną i odpowiednie miejsce w uniwersum komunikowania, o czym była mowa - na przykładzie syntez chorwackich i serbskich - w innym miejscu (zob. Czerwiński 2010a). W niniejszym tekście spróbuję doprecyzować najważniejsze mechanizmy tekstotwórcze takich książek, dając przykłady $\mathrm{z}$ historii Polski.

\section{Od rerum do verba: przeszłość, narracja, teraźniejszość}

Każda reprezentacja (każdy komunikat znakowy reprezentujący, a więc $\mathrm{z}$ a stęp uj ąc y pewien fragment rzeczywistości pozajęzykowej) - nawet jeśli jest sporządzona zgodnie $\mathrm{z}$ regułami dbałości o prawdę historyczną nie gwarantuje, że w swojej wielowymiarowości będzie uwzględniała wszelkie możliwe uwarunkowania zdarzeń przeszłych. Są one bowiem - potencjalnie rzecz ujmując - n i e o gran iczon e $e^{3}$. A skoro tak, to wnikliwemu obserwatorowi nie może umknąć następujące pytanie: w jaki sposób historyk konstruuje swoją opowieść o zdarzeniach przeszłych? Jasne jest, że tego problemu nie rozwiążemy (jest ono bowiem wielowymiarowy i frapująco zagmatwany), ale spróbujmy naświetlić pewien istotny jego wymiar.

Zdaniem rosyjskiego lingwisty i semiotyka, Borisa Uspienskiego, proces organizacji danych historycznych w słowa, zdania i bardziej złożone komunikaty odbywa się zawsze w odniesieniu do teraźni ej s zości. Uspienski, odwołując się do psychologii snu, próbuje proces porządkowania zdarzeń historycznych wyjaśnić poprzez pryzmat niespójności obrazów sennych, które ulegają fabu larnemu u porząd kow aniu za sprawą określonego fina$\nmid u^{4}$, a więc za sprawą ostatniego ogniwa w szeregu czasowym. Organizuje

${ }^{3}$ Wszyscy użytkownicy języka, w tym także historycy, obserwując świat pozajęzykowy i przekształcając go za pomocą znaków w reprezentacje (a więc zastępując aliquo przez aliquid), mogą pewne fakty i stany świata pomijać - inne eksponować, mogą jedne marginalizować - na innych ogniskować uwagę, mogą pewne fakty wiązać łańcuchem logiki przyczynowo-skutkowej - inne pozostawić poza taką relacją, mogą jedne fakty wartościować pozytywnie - inne negatywnie, na określenie jednych - stosować jeden znak, na określenie innych - stosować wiele znaków (np. peryfrazę, parafrazę, metonimię, metaforę, cały akapit, cały rozdział) itp. itd.

${ }^{4} \mathrm{O}$ konieczności zastosowania takiego zabiegu przekonują także filozofowie historii. Katarzyna Rosner, analizując filozofię Collingwooda, pisze: „Jego [historyka - M.Cz.] odtworzenie przeszłości nie jest jednak nigdy rekonstrukcją tego, co kiedyś było, ponieważ interpretuje on przeszłość z perspektywy swej własnej epoki i własnej wiedzy. Rozumienie przeszłości jest zawsze jej rozumieniem z perspektywy naszej teraźniejszości” (R o s n e r 2006, 59). Także 
ono wszystkie segmenty poprzedzające. Jeśli śnią nam się jakieś niepowiązane ze sobą obrazy, a budzi nas trzaśnięcie drzwi, możemy ów dźwięk powiązać na przykład z jakimś wystrzałem z pistoletu. Natychmiast pod ów wystrzał podporządkowuje my chaotyczne obrazy ze snu i tworzymy jakąś spójną fabułę, na przykład o tym, że przed kimś uciekaliśmy. Uspienski powiada:

Mamy tu oczywisty i wielce wyrazisty paradoks: $\mathrm{z}$ jednej strony wydaje się rzeczą niewątpliwą, że cała ta historia, którą widzimy we śnie, została sprowokowana przez hałas trzaśnięcia drzwi; z drugiej zaś strony okazuje się, że zdarzenia, które doprowadziły do tego hałasu, są z nim fabularnie związane, czyli że sam ten hałas jak gdyby był z góry założony. Tak więc $\mathrm{w}$ paradoksalny sposób zdarzenia p o p r z e d n i e zostały sprowokowane przez f in a 1, przy tym w kompozycji fabularnej, jaką widzimy we śnie, finał z poprzednimi zdarzeniami łączą związki przyczynowo-skutkowe (Uspienski 1998, 25).

Widzimy więc, że płaszczyzna oglądu, ów finał, narzuca pewną koncepcję, a więc i konceptualizację tematu głównego i z nim powiązanych zdarzeń, które zapewne nie mają (a ściślej mówiąc: nie muszą mieć) z nim związku. Zostaje on im nadany za sprawą finału. Ów temat 'nadzoruje' dobór i interpretację zdarzeń przeszłych $\mathrm{w}$ taki sposób, aby stały się one sensownie ułożoną opowieścią.

Oto trzasnęły drzwi i myśmy odebrali (zinterpretowali) we śnie ten dźwięk jako huk wystrzału. Mówiąc inaczej, odebraliśmy to zdarzenie jako znakowe i znaczące, powiązaliśmy je z określonym $\mathrm{z} n$ a c z e n i e m. Ten właśnie odbiór okazuje się, by tak rzec, d o m in a n tą semantyczną, która od razu oświetla wszystkie poprzednie zdarzenia - pozostające w naszej pamięci - determinując ich lekturę, czyli łącząc je związkami przyczynowo-skutkowymi, błyskawicznie wiążąc je w szereg fabularny. Końcowa interpretacja (percepcja, uchwycenie sensu) wyznacza, można powiedzieć, ten punkt widzenia, tę perspektywę, z której owe zdarzenia są postrzegane. Jest to swego rodzaju filtr, sito, poprzez które przesiewa się te obrazy. Te, które nie wiążą się z finalnym (znaczącym) zdarzeniem, znikają $\mathrm{z}$ naszej pamięci, są zapominane. To finalne zdarzenie $\mathrm{każ} \mathrm{nam} \mathrm{nagle}$ postrzegać wszystkie pozostałe obrazy jako treściowo

cytowany przez autorkę Danto Gallie - jeden z czołowych narratywistów - tak pisze: „Aby były badane jako historia, przeszłe ludzkie działania muszą być traktowane przez członków jakiejś ludzkiej grupy jako należące do jej przeszłości i muszą być ważne i warte rozumienia z punktu widzenia jej aktualnych interesów" (R o s n e r 2006, 66). 
powiązane ze sobą, ułożyć je w fabularnej następczoś ci. Tak więc, zdarzenia momentalnie się organizują, tworząc szereg linearny: oglądamy je naraz jak gdyby oświ etlone ni e oczekiwany m błyskie m reflekt or a. W ten sposób z góry zostaje określone $\mathrm{n}$ a s t a wienie semantyczne (kod semantyczny), które warunkuje lekturę oglądanych zdarzeń: są one odbierane o tyle o ile wiążą się w świadomości z końcowym rezultatem (Uspienski 1998, 26-27).

Spróbujmy rolę finału wytłumaczyć, odnosząc się do własnych wspomnień. W zależności od momentu, w jakim dokonujemy refleksji nad przeszłością, inaczej dobieramy zdarzenia, układamy je w nieco inne ciągi, nadajemy im inny - lub nieco inny - sens ogólny. Inaczej rozumiemy własną przeszłość, bo inaczej rozumiemy siebie po zajściu nowych okoliczności. Na różnych etapach życia jesteśmy skłonni różnym zdarzeniom czy postaciom z przeszłości nadawać różne znaczenia. To, co nam się kiedyś wydawało ważne, w innym momencie życia możemy uznać za trywialne. Każda zmiana jednej jednostki - niczym w systemie ustrukturyzowanych znaków - powoduje zmianę całego układu: zmienia ważność jednostek, a więc i cały przebieg opowieści, również jej sens ogólny. Opowiadamy sobie sami różne opowieści o nas samych, ale nie możemy powiedzieć, która z nich jest prawdziwa. $\mathrm{W}$ istocie rzeczy więc wszystkie są prawdziwe, tyle tylko że inaczej przeszłość ujmują, gdyż inne okoliczności na to ujęcie wpływają.

Każdy historyk, pisząc historię Polski na początku XXI wieku, musi przeszłość ujmować inaczej niż historyk, powiedzmy, w latach trzydziestych XX wieku, już choćby dlatego, że musi on uwzględnić także zdarzenia, które zaszły między rokiem 1930 a 2010, a chodzi o niezwykle doniosłe momenty historyczne: drugą wojnę światową z jej konsekwencjami, na przykład zmianą granic politycznych, masowymi przesiedleniami ludności, nielegalnym wprowadzeniem systemu komunistycznego, represjami wobec żołnierzy AK, a także czasy „Solidarności”, upadek komunizmu, transformację systemu politycznego, procesy integracji z zachodnimi strukturami wojskowymi i politycznymi itd. Wiedza ta, a przede wszystkim jej ujęcie w narrację, znacząco zmienia charakter oglądu i wpływa na ogólny horyzont sensu, co z kolei pociąga za sobą organizację ogniw poprzedzających. Jakże inaczej represje wobec akowców widziała historiografia peerelowska, jakże inaczej relacje polsko-żydowskie ujmowała historiografia przedwojenna! Zmiana finału zmienia stosunek do wszystkich segmentów narracji, a przez to wpływa na zmianę procesów semiozy znaków składających się na tę narrację. Jest zupełnie tak, jak w ocenie własnego życia. A zatem, teoretyczna koncepcja finału propono- 
wana przez Uspienskiego jest adekwatnym narzędziem w namyśle nad tekstami historycznymi, ponieważ umożliwia mówienie o takich tekstach nawet jeśli dzieje się „jeszcze nie skończyły”, a więc na każdym etapie ich biegu. Każdy nowy etap to bowiem nowy finat.

Finał, i za jego sprawą powstała narracja, czyli logiczny łańcuch zdarzeń, spajają niepowiązane ze sobą fakty i postacie w jedną całość, to jest $\mathrm{w}$ jeden horyzont sensu. Ukonstytuowana hipotaksa ${ }^{5}$, oparta na logicznych układach czasowych, warunkowych i przyczynowo-skutkowych, prowadzi zdarzenia do pewnego celu. Ów cel wyznacza ostatnie zdarzenie w szeregu, czyli $f i$ nał właśnie. Dzięki dominującej linii narracyjnej (w tekstach pojawiają także inne formy podawcze, opis i argumentacja, ale nie stanowią ich architektury) odbiorca ma wrażenie, że zdarzenia posuwają się w czasie w jakimś z góry określonym kierunku. Ów kierunek jest ich sensem. Teun van Dijk podkreśla także intencję jako mechanizm odróżniający zwyczajny opis zdarzeń (tylko czynności) od narracji. Narracja bowiem zakłada „kryjące się za nimi [za czynnościami] pragnienia, życzenia oraz upodobania”. I dodaje: „One to właśnie stanowią powody, dla których wykonujemy określone działania” (van Dijk 2004 [1985], 105).

Wszystkie powyżej omówione zjawiska potwierdzają pochodzące z różnych dziedzin nauki narratywistyczne ujęcia teoretyczne. W ślad za propozycją Emila Benveniste’a wyodrębnić należy dwa wymiary opowiadanej historii mowę (dyskurs) i opowieść (historię). Dwoistość ta - jak odnotowuje Bogdan Owczarek - „dobrze zdaje sprawę z niezbieżności dwóch aspektów opowiadania: narracji jako czynności i jej efektu - przedstawienia”; chodzi o opozycję, która odpowiada innym znanym opozycjom: „narracji i fabuły, mówienia i działania, komunikacji i reprezentacji” (Owczarek 2001, 18). Janina Labocha twierdzi, że francuski uczony

Przez historię rozumiał przedstawienie zdarzeń, które miały miejsce w przeszłości, w sposób całkowicie obiektywny, to znaczy wykluczający punkt widzenia jakiegokolwiek podmiotu wypowiadającego. Drugi plan wypowiedzi nazwał Benveniste dyskursem i przypisał mu wartość subiektywną, rozumiejąc przez nią odniesienie do ja nadawcy, ty odbiorcy oraz tutaj i teraz miejsca i momentu mówienia. [...] Wypowiedź historyczna znajduje wyraz w tekstach pisanych, które programowo zerują narratora, pokazując zda-

${ }^{5}$ Warto odnotować, że Aleksander Wilko ń $(2002,115)$ stwierdza, wbrew często powtarzanym tezom, iż dla czystej narracji związki hipotaktyczne są drugorzędne, liczy się „sekwencja zdarzeń": najpierw A, potem B. Narracja (czysta narracja) w tym ujęciu ma charakter parataktyczny. 
rzenia chronologiczne tak, jakby opowiadały się same. [...] Jednak również teksty pisane zawierają poziom dyskursu, wówczas gdy ich autor ujawnia się jako narrator, gdy dokonuje oceny przedstawionych zdarzeń, wprowadza postaci prowadzące dialog lub w jakiś inny sposób sygnalizuje, że przedstawiony $\mathrm{w}$ tekście świat jest widziany j e g o o c z y $\mathrm{m}$ a, relacjonowany $\mathrm{z}$ jego punktu widzenia (Labocha 1996, 51-52).

Chodzi więc o to, że z jednej strony mamy do czynienia $\mathrm{z}$ procesem komunikacji społecznej, wraz ze wszystkimi jej uwarunkowaniami i korelatami, zwłaszcza z nadawcą, odbiorcą i kontekstem, wchodzącymi ze sobą w rozmaite interakcje. $\mathrm{Z}$ drugiej zaś strony mamy konkretną opowieść, która - w zależności od owych korelatów i funkcji społecznych (wyrażonych przez wybór gatunku) - modeluje rzeczywistość przeszłą w mniej lub bardziej uporządkowane układy zdarzeniowe, w konkretną reprezentację. Opowiadanie więc - przytoczmy słowa Barbary Bokus, która opiera się na badaniach socjolingwistycznych Labova i Waletzky'ego - „to werbalna reprezentacja tego, co się zdarzyło komuś, kiedyś, gdzieś" (Bokus 2001, 63), to także odczuwanie pewnych zdarzeń jako sensownej całości. W psychologii z kolei podkreśla się charakter poznawczy narracji (czyli sposób, w jaki budowanie historii umożliwia człowiekowi - w różnych kulturach - nadanie światu sensu i jego interpretację), ale konkluzja jest zbieżna $\mathrm{z}$ tezami powyżej przytaczanymi. Na przykład Jerzy Trzebiński twierdzi, że: „gdy zrozumieliśmy coś, co minęło, jako określoną historię, zapisem tego rozumienia jest narracja, czyli opowiadanie" (Trzebiński 2001, 97); i w innym jeszcze miejscu: narracje to „umysłowe formy rozumienia świata" (Trzebiński 2001, 94). Narracja jawi się zatem jako reprezentacja czy zapis, a więc pewien układ znaków, które są rozpoznawalne w danej kulturze. Rzecz jasna oko psychologa będzie bardziej wyczulone na proces poznawczy i przetwarzanie informacji, oko badacza języka będzie się bardziej koncentrowało na strukturze zapisu albo, w przypadku nachylenia semiotycznego, na regułach kodowania i sposobie reprezentowania. Jedno jednak nie wyklucza drugiego, albowiem, jak pisze Jan Kordys w odniesieniu do autonarracji: „opowiadanie jest równocześnie aktywnością lingwistyczną i poznawczą; język oraz operacje umysłu łączą się, a powstający dyskurs, dzięki mechanizmom dostosowującym formalną strukturę opowiadania do tego, co przeżyte, tworzy mocą swych reguł konstrukcyjnych prawdę narracyjnq" (Kordys 2001, 129-130). Owczarek z kolei zauważa:

Opowiadanie na poziomie mikrostrukturalnym, odtwarza związki między podmiotem i orzeczeniem oraz innymi częściami zdania, odsłania swoją podstawową strategię, mającą dalsze konsekwencje - st r a te gi į ro zwi - 
n i ę c i a. Myśląc o zdaniu jako strukturze, w której człon określający (predykat) jest członem głównym, wskazujemy, po pierwsze, że opowiadanie realizuje się w strukturach predykatywnych i dwuczłonowych, tematyczno-rematycznych, zakładających datum i novum, pokazujących dynamiczny i „narastający” rytm opowiadania, w którym każdy następny element przynosi nową informację i uzupełnia poprzednią [...]. Narastanie opowiadania zakłada bowiem ideę następstwa, kolejności tego, co przedtem, i tego, co potem, a w efekcie przynosi wyobrażenie czasu, odsłania wreszcie związek przyczynowości, wskazując na przyczynę i skutek (Owczarek 2001, 19-20).

Narracja więc rozumiana jako ludzka umiejętność porządkowania i ujmowania zdarzeń w jednolite systemy poznawcze czy porządkowania zdarzeń w jednolite łańcuchy logiczne, jest narzędziem ustanawiania sensu. Opis zdarzeń bez narratora jawi się jako zwykła sekwencja zdarzeń. Ukonstytuowanie jednolitego sensu zdarzeń historycznych można przy tym - powiada Hayden White - uzyskać tylko przez dostosowanie „faktów do wymagań formy narracyjnej” (White 1999, 94). Co więcej, „żaden zespół przypadkowo odnotowanych wydarzeń historycznych - powiada White - nie może sam $\mathrm{z}$ siebie ułożyć się $\mathrm{w}$ opowieść; $\mathrm{w}$ najlepszym razie może on historykowi dostarczyć elementów do jej budowy" (White 1999, 83).

W tym ujęciu narracji nie należy rozumieć wyłącznie jako jednej z dostępnych podawczych form przedstawiania (komunikowania określonych danych), lecz raczej jako „czasową strukturę rozumienia” (termin Katarzyny Rosner), gdyż „odpowiada [ona] strukturze ontologicznej przedmiotu badań historycznych” (Rosner 2006, 73). Z kolei zdaniem Anny Duszak naturalna percepcja rzeczywistości, ordo naturalis, „zakłada świadomość pewnej chronologii wydarzeń, tj. ich uporządkowania czasowo-przestrzennego i ich przyczynowych uwarunkowań” (Duszak 1998, 83). Głównym celem opowiadania - dodaje Wolf-Dieter Stempel - „jest przedstawienie zmian w czasie za pośrednictwem zdarzeń - nabiera więc ono charakteru ikonicznego" (Stempel 2004, 161). Ikoniczność owa polega na tym, że ordo naturalis zdarzeń z porządku ontologicznego zostaje przeniesione w postaci znaków jako ordo signalis na płaszczyznę reprezentacji (jak się ma reprezentacja ikoniczna do tego, co reprezentowane, zob. Tabakowska 2003). W ten sposób wiedzie droga od rerum do verba. Wybór formy podawczej jest zatem wyborem konceptualizacji, stąd przedmiotem historii zatem

nie są zdarzenia fizyczne, lecz ludzkie doświadczenia i działania oraz projektowanie znaczenia na te doświadczenia i działania. Ludzkie działania mają strukturę teleologiczną i rozwijają się w czasie; podobnie czasowy charakter 
ma towarzyszące im rozumienie. Narracja, jako struktura czasowa, teleologiczna i zamknięta, odpowiada czasowości ludzkiego rozumienia. Dlatego narracja jest formą, w której to rozumienie przebiega (Rosner 2006, 73).

Ażeby lepiej zdać sprawę z tego problemu, odwołajmy się ponownie do Uspienskiego, tym razem w tym momencie jego rozważań, w którym dokonuje on rozróżnienia pomiędzy dwoma typami historii: res gestae i historia rerum gestarum. Res gestae to „całokształt zaszłych wydarzeń”, zaś historia rerum gestarum to - „opowiadanie o tym, co się wydarzyło, jako swego rodzaju tekst narracyjny" (Uspienski 1998, 20). To pierwsze to same zdarzenia przeszłe, podczas gdy to drugie to ujęcie tych zdarzeń w kategoriach procesu za sprawą mechanizmów językowych, a ściślej: w postaci narracji. Odpowiada to, przynajmniej na jakimś poziomie, podziałowi na fabułę i na konstrukcję fabularną, to jest sjużet, czyli w jakiś sposób zorganizowany układ zdarzeń (Uspienski 1998, 120). Moglibyśmy dla uproszczenia powiedzieć, że res gestae to porządek „ontologiczny”, podczas gdy historia rerum gestarum to porządek „semiotyczny” (reprezentacja znakowa), który za sprawą odpowiedniej kombinacji znaków próbuje się uobecnić pod nieobecność doświadczenia bezpośredniego, wszakże przeszłości doświadczamy za pomocą znaków (u m y sło wo ), nie jest nam dostępna bezpośrednio (z m y sło wo).

Jaka jest zależność przeszłości i teraźniejszości, odpowiada Uspienski w następujący sposób:

Jeżeli zdarzenia opisywanej rzeczywistości (historia jako res gestae) rozwijają się w czasowej następczości - od przeszłości ku teraźniejszości - to świadomość historyczna zakłada odwrotny bieg: od teraźniejs zości ku przeszłości. Świadomość historyczna pod tym względem w sposób konieczny zakłada semiozę; semiotyczna wykładnia historii winna zatem opierać się nie tylko na semiotyce języka, lecz i na semiotyce znaku, czyli na takiej dziedzinie wiedzy, dla której pojęciem pierwotnym jest właśnie pojęcie znaku, podczas gdy pojęcie języka (systemu znaków) występuje jako bardziej złożone i pochodne. Historia w sensie historia rerum gestarum jest semiotyczna ze swej natury, ponieważ zakłada określoną s e mi o ty z a cję rzeczywistości - przemianę nie-znaku w znak, nie-historii w historię (Uspienski 1998, 23-24).

Istotą świadomości historycznej jest ostatnie ogniwo - finat, gdyż to właśnie od niego historia zaczyna swój bieg, ale dzieje się to wstecz. Finat, podążając ku początkowi historii, nasyca wszystkie po drodze napotkane zdarzenia. Czym innym jest więc bieg zdarzeń w porządku ontologicz- 
nym, czym innym jest semiotyczna konstrukcja tych zdarzeń. W związku z powyższym każda semiotyczna analiza historii - już to na poziomie gatun$\mathrm{ku}$, już to na poziomie najprostszych jednostek języka - musi wyodrębnić dwie płaszczyzny czasowe, które w swojej istocie zmieniają charakter każdego oglądu: płaszczyznę czasu, w którym osadzony jest i działa (także językowo) podmiot postrzegający (czyli nadawca komunikatu językowego - narrator $)^{6}$, i płaszczyznę czasową, w której osadzony jest przed mi ot p ostrzegany (realny świat faktów i stanów rzeczy). Konstrukcja narracji historycznej jest więc swoistą dynamiczną interakcją obu płaszczyzn. Tym drugim problemem zasadniczo zajmują się historycy, którzy - za pomocą odpowiednio skonstruowanego języka - próbują opisać fakty i zdarzenia rzeczywiste (res gestae); dla semiotyka zdarzenia historyczne są konstrukcjami językowymi, realizowanymi przez język słowny reprezentacjami (historia rerum gestarum).

O ile myśl Uspienskiego przypomina White'owską koncepcję fabularnej konstrukcji procesu historycznego, o tyle z punktu widzenia rozważań zawartych w jego książce istotne jest to, że - sięgając po instrumentarium semiotyczne - unika ona radykalnego redukowania dyskursu historycznego do poziomu fikcji literackiej. W ujęciu tym historia rerum gestarum ma charakter językowy, ale jednocześnie zachowuje określony stosunek do świata pozajęzykowego (znacząco inny aniżeli dzieło literackie, zob. Czerwiński 2010b). W takim ujęciu język historiografii obserwujemy jako efekt semiotyzacji-owejprzemiany nie-znaku w znak, a więci-nie-historii $\mathrm{w}$ historię.

Zastanówmy się jeszcze, jaka jest rola finału w odniesieniu do zdarzeń poprzedzających jako ogniw stanowiących wcześniejsze segmenty narracyjne. Czytelnik dekoduje znaki i antycypuje zamknięcie, przy czym antycypacja ta wsparta jest przez wiedzę pozajęzykową („ludzie wiedzą, że opowiadania są z reguły o działaniach nastawionych na cel”, Duszak 1998, 187). Być może najlepiej to

${ }^{6}$ Podmiot postrzegający jest tu rozumiany pragmalingwistycznie, czyli jako interlokutor posiadający określoną kompetencję językowo-kulturową i określone wyposażenie ideologiczne. Będzie on, jak każdy inny interlokutor, osadzony w społecznej heteroglosji, co oznacza, że będzie jednocześnie podmiotem - w taki czy inny sposób - oceniającym. Z kolei naturę jego oceny (czyli w istocie rzeczy jego światopogląd) będziemy odczytywali ze sposobu, w jaki ów nadawca będzie organizował swoje wypowiedzi i urabiał znaczeniowo używane przez siebie słowa. Tekst o historii będzie więc nie tylko tekstem o zdarzeniach samych, lecz także o nadawcy komunikatu, a ściślej: o kodzie, jakiego jest dysponentem w przestrzeni komunikacyjnej. Taki nierozerwalny, i ciągle się aktualizujący, związek pomiędzy kodem, komunikatem, nadawcą i odbiorcą leży u podstaw każdego modelu komunikacyjnego (także tego, którego autorem jest Roman Jakobson). Zob. Cze r wińs ki 2007, 2008. 
wyjaśnić, odnosząc się do realiów nieistniejących już państw wielonarodowych, na przykład Jugosławii. Jeśli odbiorca żyje w komunistycznej Jugosławii, a czyta Historię Chorwacji (takie książki - wbrew teoriom obiegowym - wychodziły na początku lat siedemdziesiątych), to niezależnie od własnej oceny tego bytu politycznego (pozytywnej lub negatywnej) w akcie interpretacji presuponuje istnienie tego państwa. Jugosławia jest dla niego ostatnim ogniwem procesu historycznego (wcale nie musi to oznaczać, że ostatecznym!). Podobnie jest w przypadku czytelnika współczesnego, który czytając książkę o tym samym tytule, ale wydaną w latach dziewięćdziesiątych, presuponuje istnienie Chorwacji jako ostatniego ogniwa procesu historycznego. Nawet gdyby obie książki były identyczne (napisane słowo w słowo), i ch o gólny sen s byłby in ny, gdyż inny byłby ich finał, a finał właśnie narzuca właściwy sobie horyzont interpretacyjny. Jest więc finat istotny nie tylko w tworzeniu tekstu historycznego, jak twierdził Uspienski, ale także w jego odczytywaniu (dekodowaniu).

Teraz widzimy wyraźnie, dlaczego narracja jest najbardziej naturalnym sposobem ujmowania zdarzeń przeszłych. Nie chodzi wyłącznie o fakt, że jest ona - jako jedyna dostępna forma podawcza - reprezentacją zdarzeń rozwijających się w czasie. Chodzi także i o to, że narracja, za sprawą finału, ma moc spin aj ą cą, porządkuje zdarzenia w logiczne układy. Stają się one zrozumiałe tylko dzięki ich usytuowaniu w kontekście innych zdarzeń, w jakieś rela cj i z nimi, i w jakimś odniesieniu do owego finału. Bez kontekstu - i bez wiążącej roli finału - jakiekolwiek zdarzenie historyczne nie ma swojego sensu, tak jak tekst bez narratora jest zwykłą, niepowiązaną sekwencją zdarzeń. Jeśli brak jest finału, a więc i narratora, bitwa pod Grunwaldem jest po prostu zdarzeniem historycznym. Jeśli finałem jest polska niepodległość, osiągnięta pięć wieków później, wówczas Grunwald i inne bitwy - a także inne zdarzenia i postacie - stają się ogniwami łańcucha przyczyn i skutków, mającymi znaczenie $\mathrm{z}$ perspektywy finału i zarazem dla tego finału. Kontekst zatem, rozumiany lokalnie i globalnie jednocześnie, staje się elementem konstruowania znaczenia całości opowieści. Zachodzi tu sprzężenie zwrotne: ogniwa mają sens tylko za sprawą finału, podczas gdy istota finału ma sens tylko dzięki istnieniu tych ogniw. Jest podobnie jak w każdym komunikacie językowym: słowa poza kontekstem mają tylko pewne znaczenie potencjalne, ich semy gotowe są, jak pisał Greimas, do „zmartwychwstania”7.

${ }^{7}$ Algirdas Greimas twierdzi, że w każdym dyskursie taka potencjalność semantyczna (swoisty „thesaurus leksematyczny”) jest wykorzystywana zaledwie fragmentarycznie, zaś „pozostałe nadal żyją swym wirtualnym życiem, gotowe do z m a r tw y ch w s t a n i a przy najmniejszej próbie wywołania z pamięci” (Gre im a s 1970, 170, za: E co 1994, 126). 
Narracja zatem umożliwia takie sytuowanie zdarzeń (lub ich pomijanie), by mogły posiadać założoną przez narratora-autora semantykę - semantykę umożliwiającą podporządkowanie zdarzeń w sekwencję o pewnej spójnej całości. Jeśli zdarzenia uznamy za znaki systemu językowego (np. bitwa, klęska, wojna, porozumienie itd.), czyli będziemy je rozpatrywali w porządku semiotycznym, wówczas zobaczymy wyraźnie, że bez kontekstu są one tylko pewną systemową potencjalnością. Gdy zapewnimy im kontekst i powiemy o bitwie pod Płowcami, klęsce wrześniowej, wojnie trzydziestoletniej, pokoju karłowickim, wówczas nabierają one odpowiedniego znaczenia. Kontekst je ożywia i konkretyzuje, bez kontekstu - choćby nawet implikowanego $\mathrm{w}$ akcie dekodowania - są martwe.

Historia narodu, a zatem także jego definicja (rozumiana jako wi el ka encyklopedia ${ }^{8}$ ), i sens jego (za)istnienia, posiada takie same własności, co historia pojedynczego człowieka, gdyż egzystencja ludzka ma charakter czasowy. Charles Taylor mówi nawet o życiu jako „rozwijającej się opowieści” (zob. Rosner 2006, 35). Katarzyna Rosner - omawiając stanowisko Taylora - dopowiada: „Rozumienie siebie ma strukturę narracji, ponieważ jest czymś więcej niż określeniem struktury naszej teraźniejszości. Przebiega ono w trzech wymiarach czasowych: przeszłości, która opisuje to, czym jesteśmy z perspektywy tego, czym byliśmy, i przyszłości - projektowanego kierunku, projektu naszego dalszego życia”. Rozumienie ma zatem charakter narracyjny i „nadaje sens naszemu życiu, ponieważ, wiążąc ze sobą trzy perspektywy czasowe, nadaje mu ciągłość i jedność, które zapewniają integralność naszej tożsamości” (Rosner 2006, 35). Można by powiedzieć: to, dokąd zmierzamy określa to, czym jesteśmy (lub chcemy być).

\section{Finat a postacie i zdarzenia $\mathrm{w}$ historii rerum gestarum}

Dzięki temu wszystkiemu, o czym była mowa wyżej, z cienia wydobywamy jeszcze jedną właściwość tekstu historycznego, taką mianowicie, że wszyscy skonceptualizowani przez danego autora protagoniści opowieści a więc ujęte w tekście postacie historyczne - występują zawsze w jakimś stosunku do wyznaczonego kierunku dziejowego: albo go

${ }^{8}$ Kognitywistyczne szkoły badawcze zwracają uwagę, że naszą reprezentację semantyczną powinniśmy traktować nie jako słownik, lecz jako encyklopedię. Do podobnych spostrzeżeń, poza tym nurtem, doszedł także w latach siedemdziesiątych semiotyk Umberto Eco (zob. Eco 2009 [1976], 106-107). 
popierają, albo występują przeciwko niemu. Powiedzmy na razie wstępnie: postacie, które nie działają zgodnie z logiką narzuconą przez finał i narrację są najczęściej marginalizowane (stają się po prostu nierelewantne) lub też zostają opatrzone negatywnym znakiem wartości. W ten właśnie sposób powstaje klasa znaków, imion własnych, desygnujących antybohaterów i zdrajców. Na przykład w polskich syntezach, i w ogóle we współczesnej popularnonaukowej historiografii, taką rolę przypisuje się komunistom. $\mathrm{Na}$ płaszczyźnie języka dokonuje się to za sprawą wyeksponowania najbardziej relewantnych cech treści znaku komuniści, za sprawą uwypuklenia szeregu faktów: że dążyli oni do obalenia państwa międzywojennego, że nie walczyli w imię narodu polskiego, że dopuścili się szeregu zbrodni na narodzie polskim itd. To właśnie taka konceptualizacja umożliwia wybitnemu polskiemu historykowi, Jerzemu Topolskiemu, nawiasem mówiąc wieloletniemu członkowi Polskiej Zjednoczonej Partii Robotniczej, sformułowanie tezy, w myśl której polscy komuniści (Julian Marchlewski, Feliks Dzierżyński, Feliks Kon, Edward Próchniak) „opanowani ideą rewolucji weszli na drogę jawnej zdrady narodowej" (Topolski 2003, 222). Komuniści zatem zostają usytuowani na pozycjach przeciwnych właściwemu biegowi rzeczy.

W przeciwieństwie do zdrajców, postacie wspierające narzuconą linię narracyjną stają się bohaterami narodowymi par excellence. Dwa konkurencyjne zbiory protagonistów, ułożone w logicznie pogrupowane ciągi, konstytuują dwa typy postaw. Nie dziwi zatem, że w myśleniu historycznym dominuje przekonanie o istnieniu prekursorów, poprzedników czy następców. Ich obecność ma jednak sens tylko dzięki finałowi narzucającemu pewien ujednolicony horyzont sensu. $\mathrm{W}$ istocie jednak mamy do czynienia $\mathrm{z}$ różnymi egzemplarzami tego samego typu. Można powiedzieć, że mamy do czynienia $\mathrm{z}$ dwoma modelowymi protagonistami, którzy ciągle powracają do biegu zdarzeń jako nowe wcielenia tej samej idei. To oczywiście od ocen y autora zależy, kogo uzna za bohatera, kogo zaś za antybohatera. W tekstach historycznych badacze spierają się co do miejsca takiej czy innej postaci, na przykład Napoleona Bonapartego, Józefa Piłsudskiego, Lecha Wałęsy, Josipa Broza Tity itd. itp.

Uznanie jakiegoś protagonisty za bohatera lub antybohatera nosi w swojej istocie znamiona mechanizmu semantycznego, nadawca komunikatu bowiem - w akcie jego powstawania - decyduje, które cechy konotacyjne znaku wyeksponować, które zaś zmarginalizować lub zupełnie wyeliminować. I tak na przykład, dla utrzymania spójności polskiej narracji historycznej, oczywiście mówię o syntezach dziejów narodu (w książkach specjalistycznych mechanizm ów ulega dalszemu uszczegółowieniu), założycielowi Hotelu Lam- 
bert - księciu Adamowi Jerzemu Czartoryskiemu zapomina się na ogół fakt, że był ministrem spraw zagranicznych carskiej Rosji. Semantycznie rzecz ujmując, znak A. J. Czartoryski nie aktualizuje cech swojej treści dotyczących tej sfery działalności przywódcy obozu konserwatywnego. Zostają one przemilczane, a więc i treść znaku w tym kontekście zostaje odpowiednio urobiona. Oczywiście, nie znaczy to, że cechy te znikają z pola widzenia, zostają jedynie usunięte w cień, znikają tylko w tym konkretnym komunikacie i w tym konkretnym kodzie ideologicznym. W systemie językowym pozostają jako potencjalne znaczenia tego znaku, w tym momencie stają się pasywne, ale zawsze gotowe do „zmartwychwstania” wówczas, gdy ktoś - jakiś inny autor - postanowi je wydobyć $\mathrm{z}$ cienia. Taki mechanizm wydobywania z cienia pewnych cech treści stosują obecnie niektórzy historycy dążący do dyskredytacji Lecha Wałęsy.

Mamy tu do czynienia ze zwyczajnym mechanizmem uwypuklenia semantycznego. Finat, narzucając „określone nastawienie semantyczne (kod semantyczny)” warunkujący „lekturę oglądanych zdarzeń” (Uspienski 1998, 26-27), profiluje znaczenie znaków, wydobywa z nich tylko te własności, które układają się w logikę narracji, reszta zostaje zmarginalizowana.

Podobny mechanizm stosuje się przy doborze i ocenie opowiadanych zdarzeń. W narzuconym przez finat ogólnym kierunku dziejowym niektóre zdarzenia są pomijane. Jakieś zdarzenie, jeśli zostanie zmarginalizowane, „wypada z jego [społecznego adresata] pola widzenia” (Uspienski 1998, 22). Gdy pisze się syntetyczną historię Polski, jest mała szansa, abyśmy w niej znaleźli bitwę na Kosowym Polu, gdyż jest ona po prostu z perspektywy polskiego finału nierelewantna ${ }^{9}$ (ale $\mathrm{z}$ drugiej strony nie trzeba wiele trudu, by w jej treści znaleźć cechy wystarczające do narzucenia jej konotacji relewantnych dla polskiej narracji; wystarczyłoby na przykład dowieść, że w tej bitwie brało udział polskie rycerstwo albo że bitwa ta doprowadziła do ekspansji tureckiej w Europie środkowej itd.). Z kolei zdarzenia relewantne są przez autorów zawsze dobierane w jakiś konkretny sposób. Bitwa pod Grunwaldem jest relewantna dla finału, ale nie wszystkie jej cechy (konotacje) są istotne dla narracji, gdyż nie wszystkie układają się w logiczny łańcuch zdarzeń narzucony przez finał. I tak na przykład nieważne jest, że Krzyżacy cieszyli się poparciem papiestwa, albo też że po stronie zakonu walczyli

${ }^{9}$ Uspienski pisze: „[...] to, co jest znaczące z punktu widzenia danej epoki i danego obszaru historyczno-kulturowego, może w ogóle nie mieć znaczenia w systemie wyobrażeń innego obszaru historyczno-kulturowego - i odwrotnie" (Us pi enski 1998, 23). 
polscy rycerze. Co więcej, dwie ostatnie cechy mogłyby zakłócić - ustalony przez finat - sens. Wszakże istotą tego zdarzenia jest to, że konceptualizuje zakon krzyżacki jako niemiecki, nie zaś jako katolicki. Nawiasem mówiąc, rosyjskie interpretacje tego samego zakonu - formułowane z perspektywy kultury prawosławnej (nawet $\mathrm{w}$ kodach komunistycznych $\mathrm{z}$ okresu stalinowskiego) - eksponują jednocześnie dwie cechy treści tego desygnatu: germańskość i katolickość. Wyrazistym przykładem tego typu symbiozy obu cech może być słynny film Siergieja Eisensteina Aleksander Newski (1938). Krzyżacy, inaczej niż w polskich interpretacjach, są tutaj zarówno niemieccy, jak i katoliccy. Polskie kody, z oczywistych powodów, nie mogłyby sobie pozwolić na zbytnie uwypuklanie konotacji katolickiej. Dla polskiej opowieści ważny jest fakt, że bitwa pod Grunwaldem, jak i całe powstanie antykrzyżackie, wynikało $\mathrm{z}$ samowoli i okrucieństw zakonu na ziemiach polskich, że po stronie polskiej stanęły połączone siły polsko-litewskie (choć termin polsko-litewskie jest tu figurą ujednolicającą znacznie bardziej kompleksowy skład etniczny), że ziemia na polach Grunwaldu była pofałdowana, że tego dnia było gorąco itd.

Dzięki wyeksponowaniu tych, a nie innych cech wkomponow uje się to zdarzenie, te $\mathrm{n} \mathrm{kadr,} \mathrm{w} \mathrm{już} \mathrm{ustaloną} \mathrm{linię} \mathrm{narracyjną.} \mathrm{W} \mathrm{ten}$ sposób udaje się wytłumaczyć, dlaczego bitwa była konieczna i obronna (samowola na ziemiach polskich), że wojska Korony wygrały ją za sprawą swojej waleczności i bohaterstwa, sprytnie wykorzystując ukształtowanie terenu i okoliczności klimatyczno-pogodowe. Te wszystkie elementy są istotne i to one „zmartwychwstają” w tym konkretnym komunikacie. To, że w kodach rosyjskich „zmartwychwstają” dodatkowo inne cechy, wynika z innej kultury narodowej i innego finału. Nie dość bowiem, że wszystkie dobrane przez autorów cechy konotacyjne autoryzują finat (i zasadność jego istnienia), ale także stają się ogniwem dla kolejnego segmentu rozwijającej się narracji. Bez nich, a ściślej: bez ich odpowiedniego doboru, nie byłoby możliwe stworzenie sensownej hipotaksy przyczynowo-skutkowej. Trudno byłoby wytłumaczyć, dlaczego ta bitwa miała miejsce, jakie były jej przyczyny i do czego doprowadziła. A przecież tego właśnie oczekujemy od historii: że narracja wytłumaczy nam logiczny związek łączący przyczyny i skutki. Jak jednak widzieliśmy, na razie powierzchownie, jest to związek wynikający z pewnej, narzuconej przez finat i kody kulturowe/ideologiczne, interpretacji. 


\section{Postacie między działaniem a procesem}

Widzieliśmy wyżej, że postacie są zawsze usytuowane w jakimś stosunku do biegu zdarzeń. Pora wskazać, z jakimi mechanizmami mamy tu do czynienia.

Ażeby ów problem rozważyć dogłębniej i wskazać, na razie wstępnie, funkcję agensów w narracji historycznej, odwołajmy się do teorii czołowego narratywisty, Lubomíra Doležela. Jego zdaniem narracja to:

złożona struktura tekstu, w której wyróżnić można kilka wzajemnie powiązanych ze sobą makrostruktur: fabułę, opisy postaci, opisy scenerii itd. Za podstawową jednak cechę wyróżniającą teksty narracyjne możemy uznać spójną fabułę; jej to właśnie podporządkowane są inne semantyczne makrostruktury narracyjne, a nakłada ona również pewne ograniczenia na derywację form powierzchniowych (Doležel 2004 [1976], 125).

Z kolei fabuła to „pewien ciąg opowiadanych s t a n ó w (motywy statyczne) i zd arzeń (motywy dynamiczne), które orzeka się o argumentach narracji, szczególnie o agensach narratywnych" (Doležel 2004 [1976], 146). Na płaszczyźnie operacyjnej czeski narratolog wyodrębnia (wzorując się na morfemach) podstawowe jednostki narracji - motywy narracyjne, czyli „semantyczne reprezentacje przedstawionych w narracji stanów i zdarzeń. Jądrem motywu jest stwierdzenie orzekające, przypisujące jakiś predykat jednemu lub więcej argumentowi: Pred(Arg) lub Pred( $\left.\operatorname{Arg}_{1}, \operatorname{Arg}_{2}, \ldots\right)$ " (Doležel 2004 [1976], 127) ${ }^{10}$. Badania opierają się na 1) opisie semantycznym i 2) subkategoryzacji semantycznej, przy czym problemy subkategoryzacji - istotne z punktu widzenia szczegółowych opisów motywów - nie będą nas tutaj interesowały ${ }^{11}$.

${ }^{10}$ Doležel wprowadza także kategorię „komentarzy narracyjnych”, które wespół z omawianymi motywami tworzą cały pejzaż narracji. Ponieważ jednak komentarze interpretujące tekst (będące swojego rodzaju metatekstem) nie przynależą sensu stricto do narracji, nie będą tutaj omawiane, choć z punktu widzenia spójności i globalnej aksjologii tekstu są relewantne. Dopełniają bowiem znaczeniowe uniwersum tekstu. Czeski uczony wyróżnia tutaj dwa typy: stwierdzenia oceniające (np. „Szarża króla była bohaterska”) oraz predykacje o argumentach abstrakcyjnych („Polska jest dobrem wspólnym”).

${ }^{11}$ Subkategoryzacja semantyczna dotyczy zarówno stanów, jak i zdarzeń. W przypadku pierwszych motywy mogą więc a) orzekać f i z y c z n e własności i relacje o argumentach narracyjnych, np. „Król był wysokiego wzrostu” lub „Państwo Polan graniczyło z zachodu z plemionami germańskimi”; b) orzekać własności psychiczne lub psychiczne relacje o argumentach narracji, np. „Książę nie zrozumiał propozycji króla” lub „Szlachta nie darzyła 
Z punktu widzenia biegu zdarzeń istotny jest opis semantyczny. Rozpoczyna się on od rozczłonkowania wyrażenia predykatywnego (Pred) na dwa kluczowe z punktu widzenia badań wyrażenia - stan i zdarze n i e, przy czym pierwsze to „stosunkowo stałe własności argumentów bądź relacje między argumentami”, drugie zaś to „pewna zmiana (przekształcenie) jednego (początkowego) stanu w stany inny (końcowy), zachodząca w określonym punkcie czasu" (Doležel 2004 [1976], 128). Dzięki takiemu rozróżnieniu mamydwa rodzaje motywów: statyczne i dynamiczne, przy czym $\mathrm{z}$ punktu widzenia fabuły istotniejsze są te drugie.

Zdarzenia mogą być dwojakiego rodzaju: procesy (nieintencjonalne, wywoływane przez siłę nieożywioną) i d zi ała n i a (intencjonalne, zakładają istnienie agensa w postaci ożywionej). Przykładem pierwszego typu może być predykacja „Wiatr cisnął gazetą”, drugiego zaś - „Jan cisnął gazetą”. Argumenty Jan i wiatr są a fekt a nt a m i (czyli siłą sprawczą zdarzenia), zaś gazeta jest affect um (ponieważ gazeta - z racji swojej ontologii - nie może się stać afektantem, więc nie jest pacjensem, lecz obiektem; pacjens z kolei może się przekształcić w agensa, jak np. w zdaniu „Jan cisnął Piotrem”).

Podział na procesy i działania, a także wskazanie afektanta i affectum, powoduje, że można wyodrębnić cztery kategorie zdarzeniowe: a) siła procesualna (zwana także manifestacja siły) - jest zawsze afektantem (afektantem bezwzględnym): wywołuje procesy, ale nigdy nie może się stać affectum; b) a ge n s - jest afektantem, czyli wywołuje działania, ale może się stać affectum (np. "Jan bije Piotra” > „Piotr bije Jana”); c) pacjen s - jest affectum, które - jak w b) - może się stać agensem; d) obi ekt - affectum, które nie może się stać agensem, bo nigdy nie może wywoływać zdarzeń, np. „Gazeta cisnęła Janem”.

Dla budowy fabuły największe znaczenie mają a) i b), gdyż „fabuły to sekwencje opowiadanych zdarzeń z dwiema możliwymi odmianami afektantów: siłami procesualnymi i agensami narracyjnymi”, co więcej, „fabuły wynikają z wzajemnego oddziaływania afektantów" (Doležel 2004 [1976], 135).

sympatią magnaterii”; c) orzekać własności oraz relacje odnoszące się do p r y w a t n e j sfery argumentów narracyjnych; d) orzekać s p ołe c z n e role lub relacje o argumentach narracji, np. „Książę został uznany za króla”, „Król pochodził z dynastii Sasów”. W przypadku typu c) w tekście historycznym trudno znaleźć odpowiedni przykład, gdyż historia traktuje wyłącznie o publicznych aspektach osób ważnych dla jakiegoś społeczeństwa: to jest argumenty w narracji w konkretnych predykacjach nie mogą dotyczyć zwykłych ludzi, nierelewantnych kulturowo. Przykład Doležela „Jan ma trójkę dzieci” jest wystarczająco wymowny. Gdybyśmy jednak zamiast Jana podstawili Zygmunta Augusta, wówczas sprawa mogłaby być innego rodzaju, zwłaszcza jeśli chodziłoby o przedłużenie dynastii ostatniego z Jagiellonów. 
Oznacza to, że afektanty są jednymi z najważniejszych jednostek struktury narracji, a w każdej opowieści mogą występować zarówno siły procesualne, jak i agensy narracyjne, przy czym, w zależności od intencji nadawcy komunikatu, ich wzajemne współistnienie może się zmieniać. W określonych gatunkach dominować będą siły procesualne, w innych zaś - agensy narracyjne.

W kontekście analizowanej tutaj narracji historycznej istotne jest rozważanie, w jaki sposób splatają się ze sobą siły procesualne (określane potocznie mianem „biegu historii”) z agensami narracyjnymi, czyli konkretnymi postaciami - relewantnymi protagonistami procesu historycznego. Jest to pytanie istotne, gdyż nasze wyobrażenia co do czasu historycznego są mgliście niejednoznaczne. $Z$ jednej strony wydaje nam się, że historia biegnie sama $\mathrm{z}$ siebie i nikt nie może jej zatrzymać (procesy), $z$ drugiej zaś przypisujemy niektórym ważnym postaciom rolę sprawczą (działania agensów). Wówczas mówimy o nich, że zmienili bieg historii (na ile to prawda, a na ile utarta metafora pojęciowa odzwierciedlająca nasze domniemania, to sprawa filozoficzna). Najczęściej są to konkretne postaci jednostkowe (np. Mieszko I, Zygmunt Stary, Adam Jerzy Czartoryski, Józef Piłsudski) lub kategorie zbiorowe (szlachta, chłopi, Polacy, Prusacy, obywatele itd. ${ }^{12}$.

Z kolei samoistne dokonywanie się historii opiera się na założeniu, które trudniej racjonalnie wytłumaczyć, gdyż trudno pojąć, jak to się dzieje, że historia sama płynie. Procesy mają zdaniem Doležela charakter nieintencjonalny i są wywoływane przez siłę nieożywioną, np. „Wiatr cisnął gazetą”. Trzeba jednak zauważyć, że podany przykład ma charakter jednocześnie naturalny oraz nieintencjonalny i jest „pozbawioną celu zmianą stanu”, wywołaną „przez siłę nieożywioną (na przykład naturalną)” (Doležel 2004 [1976], 129). Widzimy więc, że synonimizacji tutaj ulegają kategorie nat u ral n ości i be zcelow ości. Tymczasem w tekście historycznym, w którym, jak się rzekło, celowość jest wpisana w każdy niemal poziom narracji, naturalności nie możemy wiązać $\mathrm{z}$ bezcelowością. $\mathrm{W}$ tego rodzaju narracji, być może nawet wyraźniej niż powieści realistycznej, celowość jest najważniejszym mechanizmem spójności na poziomie makro. Toteż motyw procesu ma charakter nieintencjonalny (bowiem nie stoi za nim żaden agens), ale $\mathrm{z}$ drugiej strony jest głęboko uzasadniony z punktu widzenia określanej przez finał teleologii.

${ }^{12}$ Nawiasem mówiąc, trudno sobie na przykład wyobrazić, aby w polskiej historiografii istotną funkcję agentywną pełnił - z jednej strony - Ivan Mažuranić (chorwacki pisarz i polityk), z drugiej zaś - Indianie Hopi. W tym sensie, semioza tekstu historycznego opiera się na dość solidnym kontrakcie między interlokutorami, zakładającym, że istnieją postacie relewantne historycznie, i tylko one mogą pełnić funkcje agensów relewantnych $\mathrm{z}$ punktu widzenia danej narracji i danej kultury. To jednak kwestia zupełnie innego rodzaju. 
Można nawet powiedzieć, że w prototypowym tekście historycznym wszelkie procesy dzieją się zawsze $\mathrm{w}$ jakimś celu, i w tym sensie nie są one przypadkowe, choć wywołuje je jakaś bliżej nieokreślona siła nieożywiona. Dalsze poszukiwania w tym obszarze powinny spróbować odpowiedzieć na pytanie, co to za siła.

$\mathrm{Na}$ tym etapie możemy jedynie spekulować, że narracja historyczna reprodukuje przekonanie o działaniu pewnych praw, zwanych procesami dziejowymi. Procesy te, podobnie jak procesy naturalne, są nieożywione i dokonują się jakby poza wpływem agensów - postaci historycznych. Takie przekonanie współtworzy semiozę tekstu historycznego: czytelnik (a także zapewne prototypowy autor) zakłada, że istnieje jakiś ogólny sens dziejów, w przypadku syntezy dziejów narodu chodzi o uzyskanie przez ten czy inny naród pewnego rodzaju autonomii społeczno-politycznej i kulturowej.

I w tym właśnie momencie dochodzi do splecenia procesów z d ziałaniami. Agens narracyjny, jako afektant o mniejszej „sile” niż samoistny bieg historii, może się - za sprawą odpowiedniej kompozycji narracyjnej - stać współtwórcą procesu, a więc może kategorię procesu wzmocnić swoim działaniem. Odbywa się to zazwyczaj w taki sposób, że zakłada się istnienie pewnego procesu historycznego (a więc, powtórzmy, procesu, który może wywołać tylko nieintencjonalna siła procesualna), który dokonuje się sam z siebie. A zatem żaden agens - będąc afektantem o mniejszej sile - nie ma szans owego procesu zatrzymać, może jedynie stać się jego zwolennikiem. Wówczas agens wywołuje $d z i a ł a n i a$, które jedynie ws po magają proc es (mogą go co najwyżej przyspieszyć lub opóźnić). Istotne jest jednak to, że kategoria procesu - choć zawsze nadrzędna - zaczyna współwystępować i współgrać z kategorią działania, siła procesualna zaś współwystępuje z agensem narracyjnym.

Jeżeli agens jest przeciwnikiem ustalonego przez finat procesu - a więc jeśli działa odwrotnie niż procesy dziejowe (jak na przykład komuniści w tekście Topolskiego) - wówczas staje się antybohaterem, ale z racji słabości agensów w ogóle nie może procesów zatrzymać, może je co najwyżej opóźnić.

Wszystkie te właściwości, a także zapewnie jeszcze inne, leżą u podstaw tego, że niektóre agensy podporządkowują się teleologicznemu kierunkowi narracji (potocznie rzecz ujmując, stają się zwolennikami proponowanego przez narrację ujęcia procesu historycznego), inne zaś - wprost przeciwnie - nie podporządkowują się zadanemu kierunkowi (a więc, sprzeciwiają się logice tak a nie inaczej tworzonego procesu historycznej). W taki właśnie sposób powstają omówione wyżej typy bohaterów i antybohaterów. 


\section{Zakończenie}

W tekście omówiłem kilka mechanizmów istotnych z punktu widzenia kodowania i dekodowania tekstu historycznego. Wydaje się, że rola finału jest najbardziej fundamentalna. Problem może jednak polega na tym, że termin ów jest niepokojąco pojemny (przypomnijmy: odpowiada za przebieg narracji i cały szereg innych mechanizmów). Być może więc należałoby przetestować go na większej liczbie tekstów, pochodzących nie tylko z syntez dziejów narodu. Wydaje się również, że dogłębne badania powinny usystematyzować bliskoznaczne terminy intencji i celowości narracji, gdyż tylko dzięki temu uda się we właściwy sposób uchwycić te zjawiska językowe, które wpływają na spójność tekstu i faktów przez ten tekst reprezentowanych. To być może z kolei rzuci światło na sygnalizowaną w ostatniej części rolę postaci historycznych w naturalnym biegu zdarzeń.

\section{Literatura}

Bokus B., 2001, Z analiz linii i pola narracji. O pejzażu świadomości w opowiadaniach dziecięcych, [w:] Praktyki opowiadania, red. B. Owczarek, Z. Mitosek, W. Grajewski, Kraków, s. 63-81.

Czerwiński M., 2007, Dyskursy i ich porządek w społecznej heteroglosji, „Studia z Filologii Polskiej i Słowiańskiej" 42, s. 247-268.

Czerwiński M., 2008, Kultura jako znakotwórcza przestrzeń spotkania języków, „Studia z Filologii Polskiej i Słowiańskiej" 43, s. 217-237.

Czerwiński M., 2010a, Synteza dziejów narodu - zarys problematyki stylistycznej gatunku (na podstawie teksów chorwackich i serbskich), „Studia z Filologii Polskiej i Słowiańskiej” 45 , s. 99-118.

Czerwiński M., 2010b, Gatunek jest znakiem - uwagi na marginesie dyskusji o tekście historycznym, „Pamiętnik Literacki” 2, s. 179-196

Doležel L., 2004 [1976], Semantyka narracji, [w:] Narratologia, red. M. Głowiński, tłum. M.B. Fedewicz, Gdańsk, s. 124-153.

Duszak A., 1998, Tekst, dyskurs, komunikacja międzykulturowa, Warszawa.

Eco U., 2009 [1976], Teoria semiotyki, tłum. M. Czerwiński, Kraków.

Eco U., 1994 [1974], Lector in fabula, tłum. P. Salwa, Warszawa.

Kordys J., 2001, Pamięć i opowiadanie, [w:] Praktyki opowiadania, red. B. Owczarek, Z. Mitosek, W. Grajewski, Kraków, s. 127-173

Labocha J., 1996a, Tekst, wypowiedź, dyskurs, [w:] Styl a tekst, red. S. Gajda, M. Balowski, Opole, s. 49-53.

Owczarek B., 2001, Od poetyki do antropologii opowiadania, [w:] Praktyki opowiadania, red.

B. Owczarek, Z. Mitosek, W. Grajewski, Kraków, s. 11-21

Rosner K., 2006, Narracja, tożsamość, czas, Kraków. 
Tabakowska E., 2003, Ikoniczność: podobieństwo $i$ tertium comparationis, „Przestrzenie Teorii" 2, s. 103-118.

Topolski J., 2010 [2003], Historia Polski, Poznań.

Trzebiński J., 2001, Narracja jako sposób rozumienia świata, [w:] Praktyki opowiadania, red.

B. Owczarek, Z. Mitosek, W. Grajewski, Kraków, s. 87-126

Uspienski B., 1998, Semiotyka historii, tłum. B. Żyłko, Gdańsk.

van Dijk T., 2004 [1975], Działanie, opis działania a narracja, [w:] Narratologia, red. M. Głowiński, tłum. M.B. Fedewicz, Gdańsk, s. 90-123.

White H., 2000, Poetyka pisarstwa historycznego, red. E. Domańska, M. Wilczyński, tłum.

E. Domańska i in., Kraków.

Wilkoń A., 2002, Spójność i struktura tekstu, Kraków.

\section{The understanding of national history and the structure of historical text. About some text-forming devices on the example of Polish history}

\section{( Sum mary)}

In the article some operational terms in historical text (here in the genre of the popular-scientific synthesis of a national history) are taken into consideration, notably: final (term by Boris Uspienski) and narration/narrative. It is demonstrated how the last link of a chain of events in historical representation - called by Uspienski the final - influences, and in fact enables, the very construction of any story about the past. Moreover, the final makes it possible to grasp all historical entities (protagonists, events, etc.) within a defined axiological sphere. Thus, some entities are considered to be good whereas some other are bad. Their role in a narrative is determined in relation to the final that affirms a teleology of a nation (here in the example of Polish nation). In this context, the two concepts that of event and process, taken from narratology (Doležel and van Dijk), are elaborated. 